\title{
Influence to Autoimmune Processes of Patients Suffering from Osteoarthritis
}

Khaymenova GS

Ukrainian Medical Stomatological Academy, Poltava city.

Received: February 2, 2017; Accepted: May 9, 2017; Published: September 7, 2017

*Corresponding author: Khaymenova GS, Ukrainian Medical Stomatological Academy, Poltava city, Ukraine,

E-mail: g_haymenova@mail.ru

In the past few years, it has become more obvious that osteoarthritis $(\mathrm{OA})$ is one of the most widespread chronic disabling diseases. According to different epidemiological reports, nearly $80 \%$ of the populations by the age of 60 are suffering from OA. Herewith most of them have some form of movement restriction, and $25 \%$ of them are unable to take care of themselves independently in everyday life. It is noted that $\mathrm{OA}$ is a problem, which is widespread throughout Ukraine [1, 2].

Lately, great importance in OA diagnostics has been devoted to investigate $\mathrm{OA}$ pathogenesis autoimmune components, in particular, that of hyaluronic acid antibodies (HAAB) and collagen antibodies (CAB). Since hyaluronic acid and collagen are the main components of the cartilaginous tissue matrix.

The goal of our study is to determine the benefits of magnesium oil for patients suffering from the autoimmune processes of osteoarthritis.

Testing was conducted at the rheumatology department of Poltava Regional Clinical Hospital of Sklifosovsky N.V.

30 patients were chosen for this study (11 men, 19 women, with an average age of $61 \pm 7$ years), who are suffering from OA in the poignant stage. Diagnose was determined by the guidelines of American Rheumatology Association criteria due to the clinical and radiological data complexes of OA. The main first group (I) (consisting of 15 patients) held physiotherapy courses of 10 sessions of electrophoresis in addition to Magnesium Oil application. The second (II) group of 15 patients served as control group. This group was given a course of electrophoresis with "Fastum Gel" applications.

According to the given goal special interest was taken in the examination of both HAAB and CAB levels in the blood by immunofluorescence analysis method before therapy began (outgoing data) and in dynamic treatment in the 21 days allotted for this study.

In the 21 days the $\mathrm{HAAB}$ and $\mathrm{CAB}$ levels decreased in both groups but their dynamic make up was different due to the application method (Table 1). Concentration of the HAAB and CAB in the first Group significantly decreased on average to $2,13 \pm 0,32$ units of optical density and 1,04 $\pm 0,13$ units of optical density in accordance to outgoing data $(t=2,26 ; p<0,05 i t=2,29 ; p<0,05$, accordingly). Another situation was in Group II in the analysis of the HAAB and CAB levels. Within the 21 days of the test the HAAB and $\mathrm{CAB}$ levels decreased $(2,95 \pm 0,21$ units of optical density and $1,75 \pm 0,22$ units of optical density, accordingly), but we haven't determined statistically significant differences in comparison with outgoing data $(3,54 \pm 0,73$ units of optical density and 2,43 $\pm 0,49$ units of optical density): $t=0,97 ; p>0,05, t=1,28 ; p>0,05$, respectively.

Table 1: Comparison analysis of HAAB and CAB levels in the groups of $\mathrm{OA}$ diseased who received electrophoresis with Magnesium Oil and Fastum Gel, $\mathrm{M} \pm \mathrm{m}$, units of optical density

\begin{tabular}{|c|c|c|c|c|c|}
\hline \multirow{2}{*}{\multicolumn{2}{|c|}{$\begin{array}{l}\text { Time of Blood } \\
\text { Collection } \\
\text { HAAB level }\end{array}$}} & \multicolumn{2}{|c|}{$\begin{array}{l}\text { I Group «Magnesium } \\
\text { Oil»», } \mathbf{n = 1 5}\end{array}$} & \multicolumn{2}{|c|}{$\underset{\mathbf{n}=15}{\| \text { Group «Fastum Gel» }}$} \\
\hline & & CAB level & $\begin{array}{c}\text { HAAB } \\
\text { level }\end{array}$ & CAB level & \\
\hline \multicolumn{2}{|c|}{ Start Data } & $3,76 \pm 0,76$ & $2,28 \pm 0,52$ & $3,54 \pm 0,73$ & $2,43 \pm 0,49$ \\
\hline \multirow{3}{*}{$\begin{array}{c}\text { In } 21 \\
\text { days after } \\
\text { therapy } \\
\text { beginning }\end{array}$} & & $2,13 \pm 0,32^{*}$ & $1,04 \pm 0,13^{*}$ & $2,95 \pm 0,21$ & $1,75 \pm 0,22$ \\
\hline & $\mathbf{t}$ & 2,26 & 2,29 & 0,77 & 1,28 \\
\hline & $\mathrm{P}$ & $<0,05$ & $<0,05$ & $>0,05$ & $>0,05$ \\
\hline
\end{tabular}

Remark: * - veracious differences with start data $(\mathrm{p}<0,05)$.

Thus, we saw positive treatment in the autoimmune process which continued until the treatment end in both I and II group of our OA patients in our study. 
But statistically significant differences in the HAAB and CAB levels between patients of Group I (the main group) and Group II (control group) in 21 days after treatment beginning $(\mathrm{p}<0,05)$ were discovered. Positive therapeutic influence of Magnesium Oil was discovered to influence to autoimmune component of joints inflammation and tissue destruction. This was confirmed by decreasing the leading autoimmune markers of conjunctive tissue level - antibodies for hyaluronic acid and collagen.

That, the course treatment with the Magnesium Oil allows the dramatic decreasing of autoimmune inflammation of conjunctive tissue marker levels - in both the HAAB and CAB. The influence of Magnesium Oil to autoantibody levels in cases of OA shows proof of its anti-inflammation effect, and also doesn't exclude its chondroprotector effect. Magnesium Oil helps to provide a stabilization point in the inflammation process, for added prevention of the progression and amplification of disease complications in cases of OA.

\section{References}

1. Castañeda S, Roman-Blas JA, Largo R, Herrero-Beaumont G. Osteoarthritis: a progressive disease with changing phenotypes. Rheumatology (Oxford). 2014;53(1):1-3. doi: 10.1093/rheumatology/ ket247

2. Haymanova G.S. Influence of the preparation "Magnesium oil / Magnesium oil" on the autoimmune processes in patients with osteoarthritis / G.S. Haymanova // Materials of the All-Ukrainian Scientific and Practical Conference of Young Scientists "Medical Science in Practice of Health Care", Poltava, December 9, 2016. - P. 5455. 